\title{
Photosynthesis of three evergreen broad-leaved tree species, Castanopsis sieboldii, Quercus glauca, and Q. myrsinaefolia, under elevated ozone
}

\author{
Makoto Watanabe ${ }^{(1)}$, \\ Yoshiyuki Kinose ${ }^{(1-2)}$, \\ Takeshi Izuta ${ }^{(1)}$
}

\begin{abstract}
The main goal of this study was to obtain detailed information on photosynthetic responses of evergreen broad-leaved tree species to ozone $\left(\mathrm{O}_{3}\right)$. For this, two-year-old seedlings of Castanopsis sieboldii, Quercus glauca, and $Q$. myrsinaefolia were grown for one growing season, from 15 May to 27 October 2014 under three levels of gas treatments, charcoal-filtered air and 1.0 time and 1.5 times ambient $\mathrm{O}_{3}$ concentrations. We analysed the intercellular $\mathrm{CO}_{2}$ concentration-response curve of the net photosynthetic rate, i.e., the $A / C_{i}$ curve, in July and October, and growth measurement was carried out at the end of the experiment in October. We observed a difference in $\mathrm{O}_{3}$ susceptibility among the species. Negative effects of $\mathrm{O}_{3}$ were observed on the growth and photosynthetic traits of $C$. sieboldii, while no significant effects on these traits were noted in the two Quercus species. The decrease in light-saturated net photosynthetic rate $\left(A_{\text {sat }}\right)$ of $C$. sieboldii under elevated $\mathrm{O}_{3}$ was accompanied with a significant decrease in the maximum rate of carboxylation $\left(V_{c \max }\right)$. Decreases of leaf nitrogen content and nitrogen use efficiency to Rubisco are considered as factors contributing to lower $V_{c \max }$ in $C$. sieboldii seedlings under elevated $\mathrm{O}_{3}$. In addition to the decrease in $V_{c \max }, \mathrm{O}_{3}$ exposure induced marginal increase of stomatal limitation of photosynthesis. These results indicate that both biochemical and diffusion processes in photosynthesis are responsible for the decrease in $A_{\text {sat }}$ of $C$. sieboldii under elevated $\mathrm{O}_{3}$.
\end{abstract}

Keywords: Ozone, Photosynthesis, Biochemical Limitation of Photosynthesis, Stomatal Closure, Evergreen Broad-leaved Tree Species main component species of the laurel forest, which is typical in warm temperate climate zone in East Asia with high amount of precipitation in summer. Japan is located in the northern limits of laurel forest distribution. Castanopsis sieboldii, Quercus glauca, and Q. myrsinaefolia are representative evergreen broad-leaved tree species in the laurel forests of Japan (Nakanishi et al. 1983). These species are also found in urban areas as roadside and park trees in Japan. Ozone sensitivity of evergreen trees is generally considered to be lower than that of deciduous trees (Zhang et al. 2012, Büker et al. 2015, Li et al. 2016). However, there is a great variation in $\mathrm{O}_{3}$ susceptibility within a functional type. Actually, C. siebol-
(1) Institute of Agriculture, Tokyo University of Agriculture and Technology, Fuchu, Tokyo 183-8509 (Japan); (2) Graduate Faculty of Interdisciplinary Research, University of Yamanashi, Kofu, Yamanashi 400-8510 (Japan)

@ Makoto Watanabe (nab0602@cc.tuat.ac.jp)

Received: May 17, 2017 - Accepted: Feb 25, 2018

Citation: Watanabe M, Kinose $Y$, Izuta T (2018). Photosynthesis of three evergreen broadleaved tree species, Castanopsis sieboldii, Quercus glauca, and $Q$. myrsinaefolia, under elevated ozone. iForest 11: 360-366. - doi: 10.3832/ifor2493-011 [online 2018-05-04]

Communicated by: Silvano Fares dii is considered as sensitive tree species to $\mathrm{O}_{3}$ and the sensitivity is similar to Fagus crenata, one of the most sensitive tree species to $\mathrm{O}_{3}$ in Japan (Kohno et al. 2005, Watanabe et al. 2008).

Photosynthetic carbon assimilation is one of the vital processes essential for the growth and survival of forest trees. The understanding of photosynthetic responses of trees to $\mathrm{O}_{3}$ is crucial to evaluate carbon absorption capacity of a forest under elevated $\mathrm{O}_{3}$. Photosynthetic rate in leaves is regulated by $\mathrm{CO}_{2}$ diffusion from the ambient air to chloroplasts and the biochemical assimilation capacity in chloroplasts (Farquhar \& Sharkey 1982, Lambers et al. 2008). A distinction between the process of diffusion and the biochemical assimilation by tree species with respect to the response to $\mathrm{O}_{3}$ is useful for a deeper understanding of the effects of $\mathrm{O}_{3}$ on forest production and for the future prediction of carbon sequestration and water balance of forest ecosystems under elevated $\mathrm{O}_{3}$. Kitao et al. (2009) reported that stomatal limitation of photosynthesis was the main factor behind the decrease in net photosynthetic rate while there was no effect of $\mathrm{O}_{3}$ on the maximum rate of carboxylation $\left(V_{\text {cmax }}\right)$, which is in situ activity of Rubisco, in the leaves of mature Fagus sylvatica trees. On the other hand, the opposite results were 
found in F. crenata saplings (Watanabe et al. 2013). To our knowledge, there are no current studies that separately evaluate the diffusion and biochemical processes in photosynthesis of East Asian evergreen tree species exposed to $\mathrm{O}_{3}$. Thus, there is a large uncertainty in the risk assessment of the effect of $\mathrm{O}_{3}$ on East Asian laurel forest ecosystems. In the present study, we conducted $\mathrm{O}_{3}$ fumigation study by using three representative evergreen broad-leaved tree species native to Japan, C. sieboldii, Q. glauca, and Q. myrsinaefolia, to evaluate in detail the photosynthetic responses to elevated $\mathrm{O}_{3}$.

\section{Materials and methods}

\section{Growth condition, ozone exposure, and} plant materials

Greenhouse-type $\mathrm{O}_{3}$-fumigation chambers with natural light source located at the Field Museum (FM) Tamakyuryo of Tokyo University of Agriculture and Technology ( $35^{\circ} 04^{\prime} \mathrm{N}, 139^{\circ} \mathrm{O2}{ }^{\prime} \mathrm{E}$ and $144 \mathrm{~m}$ a.s.l., Hachioji, Tokyo, Japan) were used in the present study. We set three levels of $\mathrm{O}_{3}$ treatment: charcoal-filtered air (CF, mean $\mathrm{O}_{3}$ removal efficiency: $\mathrm{ca}$. 60\%), 1.0 time ambient $\mathrm{O}_{3}$ concentration, and 1.5 times ambient $\mathrm{O}_{3}$ concentration. The ambient $\mathrm{O}_{3}$ concentration outside the chambers was used as the standard for regulating the $\mathrm{O}_{3}$ concentration in the chambers. Three chambers were used for each $\mathrm{O}_{3}$ treatment, with nine chambers in total. Further details of the fumigation and monitoring systems are described in Kinose et al. (2014).

Two-year-old seedlings of C. sieboldii, Q. glauca, and Q. myrsinaefolia were individually planted in $1 / 2000$ a Wagner's pots (bulk: 12 L, width: $228-240 \mathrm{~mm}$, depth: 259 $\mathrm{mm}$ ) filled with brown forest soil (Cambisol according to international classification system - IUSS Working Group 2015) on 8-9 May 2014. The soil was collected from the A-horizon of the floor of a deciduous forest in the FM Mt. Kusaki of Tokyo University of Agriculture and Technology $\left(36^{\circ} 03^{\prime} \mathrm{N}, 139^{\circ}\right.$ O2' E Midori, Gunma, Japan). Before planting the seedlings, the soil was passed through a 5-mm sieve. Emergence of new leaves was observed about one week after planting. Therefore, we considered little plantation shock in the present experiment. On 15 May 2014, the seedlings were transferred into nine chambers and were grown for 166 days until 27 October 2014. In each species, 12 seedlings were assigned to each gas treatment (four seedlings per chamber), with 36 seedlings in total. Mean height and stem base diameter of the seedlings were $39 \mathrm{~cm}$ and $3.9 \mathrm{~mm}$ for $C$. sieboldii, $31 \mathrm{~cm}$ and $4.8 \mathrm{~mm}$ for Q. glauca, and $33 \mathrm{~cm}$ and $4.3 \mathrm{~mm}$ for Q. myrsinaefolia, respectively. Air temperature and relative air humidity in three of the nine chambers were continuously monitored at $10 \mathrm{~min}$ intervals using a TR-72U ${ }^{\circledast}$ Thermo Recorder (T\&D Corporation, Nagano, Japan). Light intensity in three of the nine chambers were monitored at 5 min intervals using a HOBO Pendant temperature/light data logger (model UA-002-64 ${ }^{\oplus}$, Onset Computer Co., MA, USA), calibrated against a quantum sensor (model LI-190SA ${ }^{\oplus}$, Li-Cor Inc., NE, USA).

Daily mean air temperature, relative air humidity, and accumulated photosynthetic proton flux density (PPFD) inside the chambers during the experimental period (15 May to 27 October 2014) were $21.7^{\circ} \mathrm{C}$, $87.0 \%$, and $2881 \mathrm{~mol} \mathrm{~m}^{-2}$, respectively. The mean light transmissibility of the chambers was approximately $80 \%$. All seedlings were regularly irrigated to maintain soil moisture.

\section{Growth measurement}

We measured the height and stem diameter at $2 \mathrm{~cm}$ height from the soil surface and leaf number of all seedlings at the end of the experiment (27 October 2014). Leaves that emerged in 2013 and 2014 were separately counted. Stem volume index (square of diameter $\times$ height, $D^{2} H$ ) was also calculated. We dug out the root of the several seedlings after the experiment to check the root condition in the pot. Although the roots reached the bottom of the pot and circled a little, we did not find intertwining roots. Therefore, we consider the restriction of root growth due to the limited soil volume was little.

\section{Measurement of leaf gas exchange}

The gas exchange rates of matured leaves in the upper canopy of the seedlings were determined during 22-30 July and 2024 October 2014, using an open gas exchange system (LI-6400 ${ }^{\oplus}$, Li-Cor Inc., Lincoln, NE, USA). Two (July) or three (October) seedlings were selected randomly in each chamber (i.e., six or nine seedlings in each gas treatment).

The PPFD during the gas exchange measurement was maintained at $1500 \mu \mathrm{mol} \mathrm{m} \mathrm{m}^{-2}$ $\mathrm{s}^{-1}$. Leaf temperature and leaf-to-air vapour pressure deficit were maintained at $28.0 \pm$ $0.5^{\circ} \mathrm{C}$ and $1.5 \pm 0.2 \mathrm{kPa}$ in July, and $25.0 \pm$ $0.5^{\circ} \mathrm{C}$ and $1.5 \pm 0.2 \mathrm{kPa}$ in October, respectively. To obtain the intercellular $\mathrm{CO}_{2}$ concentration $\left(C_{i}\right)$-response curve of $A$, i.e., $A / C_{i}$ curve, $A$ was determined at ten $\mathrm{CO}_{2}$ concentration levels in the chamber ( $C_{a}$ - Long \& Bernacchi 2003). Firstly, we measured the gas exchange rate under a stable condition of $400 \mu \mathrm{mol} \mathrm{mol}^{-1}$ of $C_{a}$. Then, the $C_{a}$ was decreased to $60 \mu \mathrm{mol} \mathrm{mol}^{-1}$ in the following order: 300, 220, 140, and $60 \mu \mathrm{mol}$ $\mathrm{mol}^{-1}$. After the $C_{\mathrm{a}}$ was increased again to $400 \mu \mathrm{mol} \mathrm{mol}^{-1}$ and the original $A$ values were confirmed, we increased $C_{a}$ in the following order: $600,800,1100,1400$, and $1700 \mu \mathrm{mol} \mathrm{mol}^{-1}$. The $A$, stomatal conductance to water vapour, and ratio of $C_{i}$ to $C_{a}$ at $C_{a}=400 \mu \mathrm{mol} \mathrm{mol}^{-1} \mathrm{CO}_{2}\left(A_{\mathrm{sat}}, G_{\mathrm{s}}\right.$, and $C_{\mathrm{i}} / C_{\mathrm{a}}$, respectively) were calculated from the gas exchange measurement under stable condition (i.e., the first measurement log of $A / C_{i}$ curve). From the $A / C_{i}$ curve, we calculated the stomatal limitation of photosyn- thesis at $C_{a}=400 \mu \mathrm{mol} \mathrm{mol}^{-1} \mathrm{CO}_{2}$, the maximum rate of carboxylation $\left(V_{c \max }\right)$, and the maximum rate of electron transport $\left(J_{\max }-\right.$ Farquhar et al. 1980, Long \& Bernacchi 2003). Values of the Rubisco Michaelis constants for $\mathrm{CO}_{2}\left(\mathrm{~K}_{\mathrm{c}}\right)$ and $\mathrm{O}_{2}\left(\mathrm{~K}_{\mathrm{o}}\right)$, and the $\mathrm{CO}_{2}$ compensation point in the absence of dark respiration $\left(\Gamma^{*}\right)$ for analysis of the $A / C_{i}$ curve were used according to Bernacchi et al. (2001). Day respiration was considered as $2 \%$ of $V_{\text {cmax }}$ (Von Caemmerer 2000). The values of $V_{c \max }$ and $J_{\max }$ at leaf temperature of $25^{\circ} \mathrm{C}$ were calculated using their temperature dependency (Von Caemmerer 2000, Bernacchi et al. 2001). Stomatal limitation $\left(L_{s}\right)$ of photosynthesis was calculated as follows (eqn. 1):

$$
L_{s}=\frac{\left(A_{C i 400}-A_{C a 400}\right)}{A_{C i 400}}
$$

where $A_{\text {Ci40o }}$ is $A$ at $C_{\mathrm{i}}=400 \mu \mathrm{mol} \mathrm{mol}{ }^{-1} \mathrm{CO}_{2}$, and $A_{\text {Ca } 400}$ is $A$ at $C_{a}=400 \mu \mathrm{mol} \mathrm{mol}^{-1} \mathrm{CO}_{2}(=$ $A_{\text {sat }}$ - Long \& Bernacchi 2003).

\section{Measurement of leaf nitrogen content} and estimation of leaf nitrogen fraction in photosynthetic functions

After measurement of the gas exchange rate, we collected six leaf discs (diameter, $12 \mathrm{~mm}$ each) in order to determine the leaf mass per area (LMA) and nitrogen content. These leaf samples were dried in an oven for 5 days at $80^{\circ} \mathrm{C}$ and weighed. The LMA was calculated as leaf dry mass divided by leaf area. The nitrogen content of the leaves per unit mass $\left(N_{\text {mass }}\right)$ was determined using a $\mathrm{C} / \mathrm{N}$ analyser (model MT-700 ${ }^{\circledR}$, Yanaco, Tokyo, Japan). Four of six leaf discs were used for the determination. A calibration curve was generated using hippuric acid ( $\mathrm{N}=7.82 \%$ - Kishida Chemical Co., Ltd., Osaka, Japan). We calculated $N_{\text {area }}$ as the product of LMA and $N_{\text {mass }}$.

We estimated fraction of leaf nitrogen in Rubisco $\left(F_{\mathrm{nr}}\right)$ and bioenergetics (electron carriers except for photosystems, coupling factor, and Calvin cycle enzymes except Rubisco, $\left.F_{\mathrm{nb}}\right)$. The $F_{\mathrm{nr}}$ was calculated using the following equation (Niinemets et al. 1999, Tissue \& Lewis 2010 - eqn. 2):

$$
F_{n r}=\frac{V_{c \max }}{\left(6.25 \cdot V_{c r} \cdot N_{\text {area }}\right)}
$$

where $V_{c r}$ is the specific activity of Rubisco (the maximum rate of RuBP carboxylation per unit Rubisco protein), and the factor of 6.25 [g Rubisco ( $\mathrm{g} \mathrm{N}$ in Rubisco ${ }^{-1}$ ] converts nitrogen content to protein content. Here, $\mathrm{V}_{\mathrm{cr}}$ is equal to $20.5 \mu \mathrm{mol} \mathrm{CO}$ (g Rubisco) $^{-1} \mathrm{~s}^{-1}$ at $25{ }^{\circ} \mathrm{C}$ for purified Rubisco enzyme from Spinacia oleracea (Jordan \& Ogren 1984). Because this method cannot involve inactivated Rubisco, the calculated value of $F_{\mathrm{nr}}$ is an underestimate (Warren \& Adams 2004). The $F_{n b}$ was estimated from gas exchange characteristics according to the following equation (Kitaoka \& Koike 2004, Takashima et al. 2004 - eqn. 3):

$$
F_{n b}=\frac{J_{\max }}{\left(156 \cdot 9.53 \cdot N_{\text {area }}\right)}
$$


We assumed that the nitrogen in bioenergetics is proportional to $J_{\max }$, where the ratio of $J_{\max }$ to the cytochrome $f$ content is $156 \mathrm{mmol} \mathrm{mol}^{-1} \mathrm{~s}^{-1}$ (Niinemets \& Tenhunen 1997), and the nitrogen in bioenergetics per unit cytochrome $f$ is $9.53 \mathrm{~mol} \mathrm{mmol}^{-1}$ (Hikosaka \& Terashima 1995).

\section{Statistical analysis}

Statistical analyses were undertaken using $R$ software, version 3.4.0 ( $R$ Development Core Team 2017). To test the effects of $\mathrm{O}_{3}$ on leaf and growth parameters, we applied a generalized linear mixed model with average ozone concentration as a fixed-effect and difference of chamber as a random-effect. Log-transformation was applied to growth parameter before the analysis. Because we confirmed the normality for all parameters by Shapiro-Wilk test, response variables were assumed to follow Gaussian distribution in the model.

\section{Results}

The average concentrations of $\mathrm{O}_{3}$ for $24 \mathrm{~h}$

Tab. 1 - Average concentration and accumulated exposure over a threshold of 40 $\mathrm{nmol} \mathrm{mol}{ }^{-1}$ (AOT40) of ozone in each gas treatment during the experimental period for 166 days from 15 may to 27 October 2014. Each value is the mean of three chamber replicates, and the standard error is shown in parenthesis. (Daylight hours): solar radiation $>50 \mathrm{~W} \mathrm{~m}^{-2}$.

\begin{tabular}{|c|c|c|c|}
\hline \multirow[t]{2}{*}{ Treatment } & \multicolumn{2}{|c|}{$\begin{array}{l}\text { Concentration } \\
\left(\mathrm{nmol} \mathrm{mol}^{-1}\right)\end{array}$} & \multirow{2}{*}{$\begin{array}{c}\text { AOT40 } \\
\left(\mu \mathrm{mol} \mathrm{mol}^{-1} \mathrm{~h}\right) \\
\text { Daylight hours }\end{array}$} \\
\hline & 24 hour & Daylight hours & \\
\hline CF & $10.7 \pm 0.6$ & $13.0 \pm 0.8$ & $0.1 \pm 0.0$ \\
\hline $1.0 \times \mathrm{O}_{3}$ & $19.2 \pm 0.4$ & $24.3 \pm 0.2$ & $4.1 \pm 0.0$ \\
\hline $1.5 \times \mathrm{O}_{3}$ & $27.6 \pm 0.2$ & $35.8 \pm 0.2$ & $14.1 \pm 0.3$ \\
\hline
\end{tabular}

and daylight hours during the experimental period were 10.7 and $13.0 \mathrm{nmol} \mathrm{mol}^{-1}$ in CF treatment, 19.2 and $24.3 \mathrm{nmol} \mathrm{mol}^{-1}$ in 1.0 time ambient $\mathrm{O}_{3}$ treatment, and 27.6 and $35.8 \mathrm{nmol} \mathrm{mol}{ }^{-1}$ in 1.5 times ambient $\mathrm{O}_{3}$ treatment, respectively (Tab. 1). Daylight AOT40 (accumulated $\mathrm{O}_{3}$ exposure over a threshold of $40 \mathrm{nmol} \mathrm{mol}^{-1}$ with solar radiation > $50 \mathrm{~W} \mathrm{~m}^{-2}$ ) in $\mathrm{CF}, 1.0$ time, and 1.5 times ambient $\mathrm{O}_{3}$ treatments during the ex- perimental period were $0.1,4.1$, and 14.1 $\mu \mathrm{mol} \mathrm{mol}{ }^{-1} \mathrm{~h}$, respectively.

Height and $D^{2} \mathrm{H}$ of $C$. sieboldii seedlings was significantly decreased by exposure to $\mathrm{O}_{3}$, while stem diameter remained unaltered (Tab. 2). There was a tendency of $\mathrm{O}_{3}$ induced decrease in the number of 2013 leaves. We did not observe significant effects of $\mathrm{O}_{3}$ on any growth parameters examined in Q. glauca and Q. myrsinaefolia

Tab. 2 - Height, stem diameter, stem volume index (square of diameter $\times$ height, $D^{2} H$ ) and leaf number emerged in 2013 and 2014 of Castanopsis sieboldii, Quercus glauca and Q. myrsinaefolia seedlings grown under three levels of ozone fumigation at the end of the experiment. Values are means \pm standard error $(n=12)$. $(C F)$ : charcoal-filtered air; $\left(1.0 \times O_{3}\right): 1.0$ time ambient ozone concentration; $\left(1.0 \times \mathrm{O}_{3}\right): 1.5$ times ambient ozone concentration. (*): $P<0.05$; (ns): not significant. The actual $P$-values are shown when $0.05<P<$ 0.10 .

\begin{tabular}{lllllll}
\hline Species & Treament & $\begin{array}{l}\text { Height } \\
(\mathbf{c m})\end{array}$ & $\begin{array}{l}\text { Stem diameter } \\
(\mathbf{m m})\end{array}$ & $\begin{array}{l}\mathrm{D}^{2} \mathrm{H} \\
\left(\mathbf{c m}^{3}\right)\end{array}$ & \multicolumn{2}{l}{ Leaf number } \\
\hline C. sieboldii & $\mathrm{CF}$ & $124.7 \pm 3.3$ & $12.7 \pm 0.2$ & $205.3 \pm 9.8$ & $9.1 \pm 1.0$ & $200.8 \pm 10.8$ \\
& $1.0 \times \mathrm{O}_{3}$ & $115.5 \pm 3.9$ & $12.7 \pm 0.4$ & $191.2 \pm 13.8$ & $7.4 \pm 1.2$ & $195.4 \pm 11.8$ \\
& $1.5 \times \mathrm{O}_{3}$ & $108.1 \pm 2.7$ & $12.2 \pm 0.2$ & $165.3 \pm 8.6$ & $6.4 \pm 0.9$ & $179.3 \pm 10.5$ \\
& $\mathrm{Sig}$. & $*$ & $\mathrm{~ns}$ & $*$ & 0.064 & $\mathrm{~ns}$ \\
Q. glauca & $\mathrm{CF}$ & $86.6 \pm 3.9$ & $11.3 \pm 0.3$ & $115.3 \pm 10.7$ & $24.9 \pm 1.8$ & $82.9 \pm 9.8$ \\
& $1.0 \times \mathrm{O}_{3}$ & $94.6 \pm 3.0$ & $11.0 \pm 0.2$ & $115.8 \pm 6.6$ & $22.4 \pm 2.3$ & $94.8 \pm 7.0$ \\
& $1.5 \times \mathrm{O}_{3}$ & $93.3 \pm 2.6$ & $11.2 \pm 0.2$ & $117.0 \pm 5.1$ & $22.8 \pm 1.5$ & $90.4 \pm 7.4$ \\
& $\mathrm{Sig}$. & $\mathrm{ns}$ & $\mathrm{ns}$ & $\mathrm{ns}$ & $\mathrm{ns}$ & $\mathrm{ns}$ \\
Q. myrsinaefolia & $\mathrm{CF}$ & $95.1 \pm 4.0$ & $11.8 \pm 0.4$ & $136.9 \pm 14.8$ & $21.3 \pm 2.2$ & $83.6 \pm 7.3$ \\
& $1.0 \times \mathrm{O}_{3}$ & $95.0 \pm 2.9$ & $11.9 \pm 0.3$ & $135.7 \pm 6.7$ & $21.1 \pm 2.1$ & $104.0 \pm 10.0$ \\
& $1.5 \times \mathrm{O}_{3}$ & $97.2 \pm 2.9$ & $11.7 \pm 0.3$ & $133.5 \pm 9.0$ & $22.3 \pm 2.2$ & $104.3 \pm 12.5$ \\
& $\mathrm{Sig}$ & $\mathrm{ns}$ & $\mathrm{ns}$ & $\mathrm{ns}$ & $\mathrm{ns}$ & $\mathrm{ns}$ \\
\hline
\end{tabular}

Tab. 3 - Photosynthetic traits of Castanopsis sieboldii, Quercus glauca and Q. myrsinaefolia seedlings grown under three levels of ozone fumigation in July 2014. Values are means \pm standard error $(n=6)$. Abbreviations of experimental treatments are shown in Tab. 2. ( $\left.A_{\text {sat }}\right)$ : light-saturated net photosynthetic rate $\left(\mu \mathrm{mol} \mathrm{m} \mathrm{m}^{-2} \mathrm{~s}^{-1}\right) ;\left(G_{\mathrm{s}}\right)$ : stomatal conductance to water vapor $\left(\mathrm{mol} \mathrm{m} \mathrm{m}^{-2} \mathrm{~s}^{-1}\right) ;\left(C_{\mathrm{i}} / C_{\mathrm{a}}\right)$ : ratio of intercellular $\mathrm{CO}_{2}$ concentration to ambient $\mathrm{CO}_{2}$ concentration; $\left(L_{s}\right)$ : stomatal limitation of photosynthesis; $\left(V_{\text {cmax }}\right)$ : maximum rate of carboxylation $\left(\mu \mathrm{mol} \mathrm{m} \mathrm{s}^{-2}\right)$; $\left(J_{\max }\right)$ : maximum rate of electron transport $\left(\mu \mathrm{mol} \mathrm{m}^{-2} \mathrm{~s}^{-1}\right)$; $(\mathrm{ns})$ : not significant. The actual $P$-values are shown when $0.05<P<0.10$.

\begin{tabular}{llllllll}
\hline Species & Treatment & $A_{\text {sat }}$ & $G_{\mathrm{s}}$ & $C_{\mathrm{i}} / C_{\mathrm{a}}$ & $L_{\mathrm{s}}$ & $V_{\text {cmax }}$ & $J_{\max }$ \\
\hline C. sieboldii & $\mathrm{CF}$ & $16.0 \pm 0.6$ & $0.23 \pm 0.02$ & $0.63 \pm 0.03$ & $0.23 \pm 0.02$ & $73.4 \pm 6.1$ & $98.8 \pm 3.7$ \\
& $1.0 \times \mathrm{O}_{3}$ & $14.2 \pm 0.4$ & $0.19 \pm 0.02$ & $0.62 \pm 0.02$ & $0.27 \pm 0.02$ & $62.3 \pm 3.0$ & $93.8 \pm 5.6$ \\
& $1.5 \times \mathrm{O}_{3}$ & $14.8 \pm 1.3$ & $0.20 \pm 0.02$ & $0.62 \pm 0.02$ & $0.26 \pm 0.02$ & $65.7 \pm 7.4$ & $97.0 \pm 7.7$ \\
& Sig. & $\mathrm{ns}$ & $\mathrm{ns}$ & $\mathrm{ns}$ & $\mathrm{ns}$ & $\mathrm{ns}$ & $\mathrm{ns}$ \\
Q. glauca & $\mathrm{CF}$ & $12.7 \pm 1.4$ & $0.13 \pm 0.02$ & $0.56 \pm 0.03$ & $0.36 \pm 0.04$ & $81.1 \pm 11.1$ & $112.8 \pm 8.9$ \\
& $1.0 \times \mathrm{O}_{3}$ & $11.4 \pm 0.8$ & $0.13 \pm 0.02$ & $0.57 \pm 0.03$ & $0.30 \pm 0.04$ & $68.5 \pm 1.6$ & $96.7 \pm 4.3$ \\
& $1.5 \times \mathrm{O}_{3}$ & $12.6 \pm 0.5$ & $0.15 \pm 0.02$ & $0.61 \pm 0.02$ & $0.30 \pm 0.03$ & $73.1 \pm 3.0$ & $104.6 \pm 6.1$ \\
& $\mathrm{Sig}$. & $\mathrm{ns}$ & $\mathrm{ns}$ & $\mathrm{ns}$ & $\mathrm{ns}$ & $\mathrm{ns}$ & $\mathrm{ns}$ \\
Q. myrsinaefolia & $\mathrm{CF}$ & $12.2 \pm 0.4$ & $0.18 \pm 0.01$ & $0.63 \pm 0.01$ & $0.25 \pm 0.01$ & $62.4 \pm 1.7$ & $93.7 \pm 3.4$ \\
& $1.0 \times \mathrm{O}_{3}$ & $12.7 \pm 0.3$ & $0.16 \pm 0.01$ & $0.63 \pm 0.01$ & $0.26 \pm 0.01$ & $67.2 \pm 2.2$ & $100.0 \pm 2.5$ \\
& $1.5 \times \mathrm{O}_{3}$ & $13.1 \pm 0.4$ & $0.18 \pm 0.02$ & $0.65 \pm 0.02$ & $0.24 \pm 0.03$ & $67.7 \pm 3.3$ & $101.1 \pm 5.9$ \\
& $\mathrm{Sig}$. & 0.083 & $\mathrm{~ns}$ & $\mathrm{~ns}$ & $\mathrm{~ns}$ & $\mathrm{~ns}$ & $\mathrm{~ns}$ \\
\hline
\end{tabular}


Tab. 4 - Photosynthetic traits of Castanopsis sieboldii, Quercus glauca and Q. myrsinaefolia seedlings grown under three levels of ozone fumigation in October 2014. Values are means \pm standard error $(n=9)$. Abbreviations of experimental treatments and photosynthetic parameters are shown in Tab. 2 and Tab. 3 respectively. $\left(^{*}\right): P<0.05 ;(n s)$ : not significant. The actual $P$-values are shown when $0.05<P<0.10$.

\begin{tabular}{llllllll}
\hline Species & Treatment & $A_{\text {sat }}$ & $G_{\mathrm{s}}$ & $C_{\mathrm{i}} / C_{\mathrm{a}}$ & $L_{\mathrm{s}}$ & $V_{\text {cmax }}$ & $J_{\max }$ \\
\hline C. sieboldii & $\mathrm{CF}$ & $13.8 \pm 0.8$ & $0.17 \pm 0.01$ & $0.63 \pm 0.01$ & $0.24 \pm 0.02$ & $74.3 \pm 4.5$ & $126.7 \pm 9.9$ \\
& $1.0 \times \mathrm{O}_{3}$ & $14.1 \pm 0.5$ & $0.17 \pm 0.01$ & $0.63 \pm 0.01$ & $0.25 \pm 0.02$ & $72.7 \pm 2.5$ & $126.2 \pm 5.2$ \\
& $1.5 \times \mathrm{O}_{3}$ & $11.9 \pm 0.4$ & $0.14 \pm 0.01$ & $0.62 \pm 0.02$ & $0.30 \pm 0.03$ & $61.7 \pm 2.5$ & $113.7 \pm 5.1$ \\
& $\mathrm{Sig}$. & $*$ & $\mathrm{~ns}$ & $\mathrm{~ns}$ & 0.094 & $* *$ & $\mathrm{~ns}$ \\
Q. glauca & $\mathrm{CF}$ & $15.1 \pm 0.5$ & $0.18 \pm 0.01$ & $0.62 \pm 0.01$ & $0.36 \pm 0.01$ & $79.9 \pm 2.2$ & $163.2 \pm 4.9$ \\
& $1.0 \times \mathrm{O}_{3}$ & $15.4 \pm 0.7$ & $0.19 \pm 0.01$ & $0.64 \pm 0.01$ & $0.33 \pm 0.02$ & $79.4 \pm 3.4$ & $155.7 \pm 4.5$ \\
& $1.5 \times \mathrm{O}_{3}$ & $15.4 \pm 0.6$ & $0.20 \pm 0.01$ & $0.65 \pm 0.02$ & $0.34 \pm 0.01$ & $78.6 \pm 2.4$ & $160.2 \pm 5.8$ \\
& $\mathrm{Sig}$. & $\mathrm{ns}$ & $\mathrm{ns}$ & $\mathrm{ns}$ & $\mathrm{ns}$ & $\mathrm{ns}$ & $\mathrm{ns}$ \\
Q. myrsinaefolia & $\mathrm{CF}$ & $14.1 \pm 0.6$ & $0.16 \pm 0.01$ & $0.62 \pm 0.02$ & $0.35 \pm 0.02$ & $76.6 \pm 5.4$ & $156.6 \pm 10.2$ \\
& $1.0 \times \mathrm{O}_{3}$ & $13.2 \pm 0.8$ & $0.15 \pm 0.01$ & $0.60 \pm 0.02$ & $0.35 \pm 0.02$ & $71.4 \pm 3.6$ & $140.7 \pm 7.7$ \\
& $1.5 \times \mathrm{O}_{3}$ & $13.3 \pm 0.4$ & $0.15 \pm 0.01$ & $0.61 \pm 0.02$ & $0.36 \pm 0.02$ & $70.9 \pm 3.4$ & $140.9 \pm 6.3$ \\
& $\mathrm{Sig}$. & $\mathrm{ns}$ & $\mathrm{ns}$ & $\mathrm{ns}$ & $\mathrm{ns}$ & $\mathrm{ns}$ & $\mathrm{ns}$ \\
\hline
\end{tabular}

Tab. 5 - Leaf mass per area (LMA, $\left.\mathrm{g} \mathrm{m}^{-2}\right)$, mass- and area-based nitrogen content ( $N_{\text {mass }}$ and $N_{\text {area }} \%$ and $g$ m ${ }^{-2}$, respectively) and fraction of leaf nitrogen in Rubisco $\left(F_{\mathrm{nr}}\right)$ and bioenergetics (electron carriers except for photosystems, coupling factor and Calvin cycle enzymes except Rubisco, $F_{\mathrm{nb}}$ ) of Castanopsis sieboldii, Quercus glauca and Q. myrsinaefolia seedlings grown under three levels of ozone fumigation in July 2014. Values are means \pm standard error $(n=6)$. Abbreviations of experimental treatments are shown in Tab. 2. (ns): not significant. The actual $P$-values are shown when $0.05<P<0.10$.

\begin{tabular}{lllllll}
\hline Species & Treatment & LMA & $N_{\text {mass }}$ & $N_{\text {area }}$ & $F_{\mathrm{nr}}$ & $F_{\mathrm{nb}}$ \\
\hline C. sieboldii & $\mathrm{CF}$ & $80.2 \pm 1.7$ & $2.34 \pm 0.07$ & $1.88 \pm 0.08$ & $0.301 \pm 0.022$ & $0.036 \pm 0.001$ \\
& $1.0 \times \mathrm{O}_{3}$ & $75.7 \pm 1.8$ & $2.42 \pm 0.07$ & $1.83 \pm 0.04$ & $0.264 \pm 0.013$ & $0.034 \pm 0.002$ \\
& $1.5 \times \mathrm{O}_{3}$ & $76.5 \pm 2.9$ & $2.34 \pm 0.04$ & $1.79 \pm 0.09$ & $0.281 \pm 0.019$ & $0.036 \pm 0.002$ \\
& $\mathrm{Sig}$. & $\mathrm{ns}$ & $\mathrm{ns}$ & $\mathrm{ns}$ & $\mathrm{ns}$ & $\mathrm{ns}$ \\
Q. glauca & $\mathrm{CF}$ & $95.5 \pm 3.7$ & $2.21 \pm 0.10$ & $2.10 \pm 0.05$ & $0.298 \pm 0.038$ & $0.036 \pm 0.003$ \\
& $1.0 \times \mathrm{O}_{3}$ & $90.5 \pm 2.3$ & $2.20 \pm 0.05$ & $1.99 \pm 0.07$ & $0.268 \pm 0.010$ & $0.033 \pm 0.002$ \\
& $1.5 \times \mathrm{O}_{3}$ & $97.4 \pm 2.2$ & $2.26 \pm 0.04$ & $2.19 \pm 0.04$ & $0.258 \pm 0.011$ & $0.032 \pm 0.002$ \\
& $\mathrm{Sig.}$ & $\mathrm{ns}$ & $\mathrm{ns}$ & $\mathrm{ns}$ & $\mathrm{ns}$ & $\mathrm{ns}$ \\
Q. myrsinaefolia & $\mathrm{CF}$ & $88.7 \pm 2.2$ & $2.02 \pm 0.03$ & $1.79 \pm 0.07$ & $0.271 \pm 0.007$ & $0.035 \pm 0.001$ \\
& $1.0 \times \mathrm{O}_{3}$ & $87.0 \pm 2.5$ & $2.07 \pm 0.05$ & $1.80 \pm 0.03$ & $0.290 \pm 0.011$ & $0.037 \pm 0.001$ \\
& $1.5 \times \mathrm{O}_{3}$ & $85.1 \pm 1.5$ & $2.12 \pm 0.04$ & $1.80 \pm 0.02$ & $0.290 \pm 0.012$ & $0.038 \pm 0.002$ \\
& $\mathrm{Sig.}$ & $\mathrm{ns}$ & 0.081 & $\mathrm{~ns}$ & $\mathrm{~ns}$ & $\mathrm{~ns}$ \\
\hline
\end{tabular}

seedlings.

There were no significant effects of $\mathrm{O}_{3}$ on gas exchange parameters of all tree species in July, although the $A_{\text {sat }}$ of Q. myrsinaefolia showed a tendency to increase after exposure to $\mathrm{O}_{3}$ (Tab. 3). In October, we observed significant $\mathrm{O}_{3}$-induced decreases eters of $\mathrm{Q}$. glauca and Q. myrsinaefolia in $A_{\text {sat }}$ and $V_{\text {cmax }}$ of $C$. sieboldii seedlings seedlings in October. We found no signifi(Tab. 4). In addition, there was a tendency cant effects of $\mathrm{O}_{3}$ on LMA, leaf nitrogen of increase in $L_{s}$ of photosynthesis with in- content and leaf nitrogen fraction in phocreasing exposure to $\mathrm{O}_{3}$. The exposure to tosynthetic functions in any of the tree $\mathrm{O}_{3}$ did not affect any gas exchange param- species studied in July and October, except

Tab. 6 - Leaf mass per area (LMA, $\mathrm{g} \mathrm{m}^{-2}$ ), mass- and area-based nitrogen content ( $N_{\text {mass }}$ and $N_{\text {area, }} \%$ and $g$ m $\mathrm{m}^{-2}$, respectively) and fraction of leaf nitrogen in Rubisco $\left(F_{\mathrm{nr}}\right)$ and bioenergetics (electron carriers except for photosystems, coupling factor and Calvin cycle enzymes except Rubisco, $F_{\mathrm{nb}}$ ) of Castanopsis sieboldii, Quercus glauca and Q. myrsinaefolia seedlings grown under three levels of ozone fumigation in October 2014. Values are means \pm standard error $(n=9)$. Abbreviations of experimental treatments are shown in Tab. 2. (ns): not significant. The actual $P$-values are shown when $0.05<P<0.10$.

\begin{tabular}{lllllll}
\hline Species & Treatment & LMA & $N_{\text {mass }}$ & $N_{\text {area }}$ & $F_{\mathrm{nr}}$ & $\boldsymbol{F}_{\mathrm{nb}}$ \\
\hline C. sieboldii & $\mathrm{CF}$ & $94.6 \pm 1.6$ & $2.13 \pm 0.09$ & $2.00 \pm 0.06$ & $0.288 \pm 0.015$ & $0.043 \pm 0.003$ \\
& $1.0 \times \mathrm{O}_{3}$ & $92.5 \pm 2.1$ & $2.08 \pm 0.07$ & $1.92 \pm 0.07$ & $0.296 \pm 0.015$ & $0.045 \pm 0.002$ \\
& $1.5 \times \mathrm{O}_{3}$ & $88.8 \pm 2.8$ & $2.08 \pm 0.09$ & $1.83 \pm 0.05$ & $0.260 \pm 0.006$ & $0.042 \pm 0.002$ \\
& $\mathrm{Sig}$. & $\mathrm{ns}$ & $\mathrm{ns}$ & 0.063 & $\mathrm{~ns}$ & $\mathrm{~ns}$ \\
Q. glauca & $\mathrm{CF}$ & $97.3 \pm 1.6$ & $2.58 \pm 0.05$ & $2.51 \pm 0.04$ & $0.247 \pm 0.008$ & $0.044 \pm 0.001$ \\
& $1.0 \times \mathrm{O}_{3}$ & $97.0 \pm 2.6$ & $2.58 \pm 0.04$ & $2.50 \pm 0.08$ & $0.246 \pm 0.008$ & $0.042 \pm 0.001$ \\
& $1.5 \times \mathrm{O}_{3}$ & $99.1 \pm 2.0$ & $2.60 \pm 0.06$ & $2.57 \pm 0.07$ & $0.237 \pm 0.008$ & $0.042 \pm 0.001$ \\
& $\mathrm{Sig.}$ & $\mathrm{ns}$ & $\mathrm{ns}$ & $\mathrm{ns}$ & $\mathrm{ns}$ & $\mathrm{ns}$ \\
Q. myrsinaefolia & $\mathrm{CF}$ & $92.8 \pm 1.8$ & $2.54 \pm 0.14$ & $2.36 \pm 0.14$ & $0.251 \pm 0.008$ & $0.045 \pm 0.002$ \\
& $1.0 \times \mathrm{O}_{3}$ & $89.6 \pm 2.3$ & $2.62 \pm 0.08$ & $2.34 \pm 0.08$ & $0.236 \pm 0.009$ & $0.040 \pm 0.001$ \\
& $1.5 \times \mathrm{O}_{3}$ & $88.8 \pm 2.6$ & $2.49 \pm 0.05$ & $2.22 \pm 0.09$ & $0.248 \pm 0.010$ & $0.043 \pm 0.002$ \\
& Sig. & $\mathrm{ns}$ & $\mathrm{ns}$ & $\mathrm{ns}$ & $\mathrm{ns}$ & $\mathrm{ns}$ \\
\hline
\end{tabular}


for $N_{\text {mass }}$ of Q. myrsinaefolia in July and $N_{\text {area }}$ of C. sieboldii in October (Tab. 5 and Tab. $6)$. There were tendencies of $\mathrm{O}_{3}$-induced increase in $N_{\text {mass }}$ of $Q$. myrsinaefolia in July and decrease in $\mathrm{N}_{\text {area }}$ of $\mathrm{C}$. sieboldii in October.

\section{Discussion}

We observed a difference in $\mathrm{O}_{3}$ susceptibility among the three tree species. According to the photosynthetic and growth responses to $\mathrm{O}_{3}$, C. sieboldii showed higher susceptibility than the other two Quercus species. The higher susceptibility of $C$. sieboldii to $\mathrm{O}_{3}$ is in agreement with the results of our previous studies (Kohno et al. 2005, Watanabe et al. 2008).

The difference of $\mathrm{O}_{3}$ uptake into the leaves through the stomata is considered an important factor in determining the different susceptibilities to $\mathrm{O}_{3}$ among the tree species (Karlsson et al. 2007). Stomatal $\mathrm{O}_{3}$ uptake rate can be explained by stomatal conductance to $\mathrm{O}_{3}\left(\mathrm{G}_{\mathrm{O}_{3}}\right)$ when the meteorological condition and atmospheric $\mathrm{O}_{3}$ concentration are the same. The $\mathrm{G}_{\mathrm{O}_{3}}$ is proportional to $G_{s}$ with a proportionality constant of 0.663 (i.e., $G_{0_{3}}=0.663 G_{s}$ - Mills et al. 2017). Thus, the difference of $G_{s}$ among tree species is considered a good indicator of the difference of stomatal $\mathrm{O}_{3}$ uptake. However, there was no great difference between $G_{s}$ of $C$. sieboldii and that of the other two Quercus species (Tab. 3 and Tab. 4), indicating that the amount of $\mathrm{O}_{3}$ uptake would not be largely different among these trees and would not serve as the main parameter to evaluate the difference in $\mathrm{O}_{3}$ susceptibility.

Some Quercus species emit biogenic volatile organic compounds (BVOCs), mainly isoprene, and the BVOC may act as a detoxifying substance for $\mathrm{O}_{3}$ and reactive oxygen species (Loreto \& Fares 2013). However, the BVOC emission varied among the Quercus species. According to Tani \& Kawawata (2008), Q. glauca and Q. myrsinaefolia, which are tolerant species to $\mathrm{O}_{3}$ in the present study, do not emit BVOC. Li et al. (2016) suggested that LMA is a potentially useful indicator for evaluating $\mathrm{O}_{3}$ susceptibility based on an analysis using 29 tree species, both deciduous and evergreen. In the present study, however, we observed quite similar values of LMA for the three species. Although the reasons for the different $\mathrm{O}_{3}$ susceptibilities between $\mathrm{C}$. sieboldii and the two Quercus species are not clear, it is clear that not all evergreen broad-leaved tree species are tolerant to $\mathrm{O}_{3}$ (Zhang et al. 2012, Büker et al. 2015, Li et al. 2016). Further screening studies must be conducted to find other " $\mathrm{O}_{3}$-sensitive" evergreen broad-leaved tree species, especially in the genus Castanopsis.

The decrease in $A_{\text {sat }}$ of $C$. sieboldii was accompanied by a significant decrease in $V_{\text {cmax }}$, marginal decrease in $G_{s}$, and increase in $L_{s}$ (Tab. 4). This indicates that both biochemical and diffusion processes in photosynthesis are responsible for the decrease in $\mathrm{A}_{\text {sat }}$ under elevated $\mathrm{O}_{3}$, although the contribution of the former may be higher to some degree. $\mathrm{O}_{3}$-induced decrease in $\mathrm{V}_{\mathrm{cmax}}$ was reported in several Japanese deciduous tree species (Hoshika et al. 2013a, 2013b, Watanabe et al. 2013, 2014). The $V_{\text {cmax }}$ represents in situ activity of Rubisco (Farquhar et al. 1980, Lambers et al. 2008), and a decrease in Rubisco content under elevated $\mathrm{O}_{3}$ was also reported in deciduous trees (Yamaguchi et al. 2007, Watanabe et al. 2007).

In contrast to $\mathrm{V}_{\text {cmax }}, \mathrm{O}_{3}$-induced decrease of $J_{\max }$ in C. sieboldii seedlings was not observed (Tab. 4), although decreases in both $V_{c \max }$ and $J_{\max }$ under elevated $\mathrm{O}_{3}$ were reported in several studies of deciduous trees native to Japan (Hoshika et al. 2012, 2013b, Watanabe et al. 2013). Kinose et al. (2017) indicated that the timing of significant $\mathrm{O}_{3}$-induced decrease in $\mathrm{V}_{\mathrm{cmax}}$ was earlier than that in $J_{\max }$ of $F$. crenata seedlings. There is a possibility that the first effect of $\mathrm{O}_{3}$ on the biochemical process of photosynthesis occurs in carboxylation by Rubisco.

Nitrogen is a nutrient that is strongly related to the biochemical assimilation capacity of plants (Lambers et al. 2008). A large fraction of nitrogen in the leaves is incorporated into proteins associated with the photosynthetic process (Evans 1989), and the biggest destination of nitrogen investment is Rubisco (Niinemets et al. 1999, Takashima et al. 2004, Watanabe et al. 2012). In the present study, we observed marginally significant decrease in $\mathrm{N}_{\text {area }}$ and no significant decrease in $F_{n r}$ of $C$. sieboldii seedlings under elevated $\mathrm{O}_{3}$. However, the reduction rates of $N_{\text {area }}$ and $F_{\mathrm{nr}}$ are similar, $8.5 \%$ and $9.7 \%$, respectively, in 1.5 times ambient $\mathrm{O}_{3}$ treatment compared to $\mathrm{CF}$ treatment. Therefore, we consider both factors (i.e., nitrogen content and nitrogen use efficiency to Rubisco) contribute to the decrease in $\mathrm{V}_{\text {cmax }}$ under elevated $\mathrm{O}_{3}$

We observed elevated $\mathrm{O}_{3}$-induced increase of $L_{s}$ in C. sieboldii seedlings (Tab. 4). A similar result was observed in mature $F$. sylvatica (Kitao et al. 2009), but it is in contrast with the results of many other studies of deciduous tree species. Hoshika et al. (2013a) reported the avoidance of $\mathrm{O}_{3}$ uptake by stomatal closure in $F$. crenata saplings in early summer, but not in late summer and autumn. Plant physiological studies have shown several mechanisms of $\mathrm{O}_{3}$-induced stomatal closure such as direct modulation of $\mathrm{K}^{+}$channels (Torsethaugen et al. 1999, Vahisalu et al. 2010), change of $\mathrm{Ca}^{2+}$ homeostasis in guard cells (McAinsh et al. 2002), and production of phytohormones (Overmyer et al. 2008).

\section{Conclusions}

To our knowledge, this is the first study to analyse photosynthesis with respect to diffusion and biochemical processes in the leaves of East Asian evergreen tree species under elevated $\mathrm{O}_{3}$. High $\mathrm{O}_{3}$ susceptibilities on photosynthesis and growth in C. sieboldii were confirmed. On the other hand, the two Quercus species showed high tolerance against $\mathrm{O}_{3}$. The negative effect of $\mathrm{O}_{3}$ on net photosynthesis of C. sieboldii was due to decreases in both diffusion (increase in $L_{s}$ ) and biochemical processes (decrease in $\left.V_{\text {cmax }}\right)$. These results indicate that not only the decrease in carbon absorption capacity but also the change in water balance due to stomatal closure should be considered as risks for $C$. sieboldii forest under elevated $\mathrm{O}_{3}$.

\section{Acknowledgments}

The authors are greatly indebted to Mr. Yoshinobu Fukamachi, Ms. Hiroka Hiroshima, and Mr. Shigeaki Okabe (Tokyo University of Agriculture and Technology) for their technical support, and to Dr. Hayato lijima for the advice of statistical analysis. This study was supported by JSPS KAKENHI, Young Scientists B (15K16136 to $\mathrm{MW}$ ), and Challenging Exploratory Research (15K12217 to TI and MW). We would like to thank Editage (http://www.editage. jp) for English language editing.

\section{References}

Bernacchi CJ, Singsaas EL, Pimentel C, Portis Jr AR, Long SP (2001). Improved temperature response functions for models of Rubisco-limited photosynthesis. Plant, Cell and Environment 24: 253-259. - doi: 10.1111/j.1365-3040.2001. 00668.x

Büker P, Feng Z, Uddling J, Briolat A, Alonso R, Braun $S$, Elvira $S$, Gerosa $G$, Karlsson PE, Le Thiec D, Marzuoli R, Mills G, Oksanen E, Wieser G, Wilkinson M, Emberson LD (2015). New flux based dose-response relationships for ozone for European forest tree species. Environmental Pollution 206: 163-174. - doi: 10.1016/j.envpol. 2015.06.033

Evans JR (1989). Photosynthesis and nitrogen relationships in leaves of $C_{3}$ plants. Oecologia 78: 9-19. - doi: 10.1007/BF00377192

Farquhar GD, Sharkey TD (1982). Stomatal conductance and photosynthesis. Annual Review of Plant Physiology 33: 317-345. - doi: 10.1146/ annurev.pp.33.060182.001533

Farquhar GD, Von Caemmerer S, Berry JA (1980). A biochemical model of photosynthetic $\mathrm{CO}_{2}$ assimilation in leaves of $\mathrm{C}_{3}$ species. Planta 149: 78-90. - doi: 10.1007/BF00386231

Hikosaka K, Terashima I (1995). A model of the acclimation of photosynthesis in the leaves of $C_{3}$ plants to sun and shade with respect to nitrogen use. Plant, Cell and Environment 18: 605-618. - doi: 10.1111/j.1365-3040.1995.tbo056 $2 . x$

Hoshika Y, Watanabe M, Inada N, Koike T (2012). Growth and leaf gas exchange in three birch species exposed to elevated ozone and $\mathrm{CO}_{2}$ in summer. Water, Air and Soil Pollution 223: 50175025. - doi: 10.1007/s11270-012-1253-y

Hoshika $\mathrm{Y}$, Watanabe $\mathrm{M}$, Inada $\mathrm{N}$, Koike $\mathrm{T}$ (2013a). Model-based analysis of avoidance of ozone stress by stomatal closure in Siebold's beech (Fagus crenata). Annals of Botany 112: 1149-1158. - doi: 10.1093/aob/mct166 Hoshika Y, Watanabe M, Inada N, Mao Q, Koike T (2013b). Photosynthetic response of early and late leaves of white birch (Betula platyphylla 
var. japonica) grown under free-air ozone exposure. Environmental Pollution 182: 242-247. doi: 10.1016/j.envpol.2013.07.033

IUSS Working Group WRB (2015). World reference base for soil resources 2014, update 2015 . International soil classification system for naming soils and creating legends for soil maps. World soil resources reports no. 106, FAO, Rome, Italy, pp. 192. [online] URL: http:// www.fao.org/3/a-i3794e.pdf

Jordan DB, Ogren WL (1984). The CO2/O2 specificity of ribulose 1.5-bisphosphate carboxylase/oxygenase. Dependence on ribulose bisphosphate concentration, $\mathrm{pH}$ and temperature. Planta 161: 308-313. - doi: 10.1007/BF00398720

Karlsson PE, Braun S, Broadmeadow M, Elvira S, Emberson LD, Gimeno BS, Le Thiec D, Novak K, Oksanen E, Schaub M, Uddling J, Wilkinson M (2007). Risk assessments for forest trees: the performance of the ozone flux versus the AOT concepts. Environmental Pollution 146: 608616. - doi: 10.1016/j.envpol.2006.06.012

Kinose Y, Azuchi F, Uehara Y, Kanomata T, Kobayashi A, Yamaguchi M, Izuta T (2014). Modeling of stomatal conductance to estimate stomatal ozone uptake by Fagus crenata, Quercus serrata, Quercus mongolica var. crispula and Betula platyphylla. Environmental Pollution 194: 235-245. - doi: 10.1016/j.envpol.2014.07.030

Kinose Y, Fukamachi Y, Okabe S, Hiroshima H, Watanabe M, Izuta T (2017). Photosynthetic responses to ozone of upper and lower canopy leaves of Fagus crenata Blume seedlings grown under different soil nutrient conditions. Environmental Pollution 223: 213-222. - doi: 10.1016/j. envpol.2017.01.014

Kitao M, Löw M, Heerdt C, Grams TEE, Häberle $\mathrm{K}-\mathrm{H}$, Matyssek R (2009). Effects of chronic elevated ozone exposure on gas exchange responses of adult beech trees (Fagus sylvatica) as related to the within-canopy light gradient. Environmental Pollution 157: 537-544. - doi: 10.1016/j.envpol.2008.09.016

Kitaoka S, Koike T (2004). Invasion of broad-leaf tree species into a larch plantation: seasonal light environment, photosynthesis and nitrogen allocation. Physiologia Plantarum 121: 604611. - doi: 10.1111/j.1399-3054.2004.00359.x

Kohno Y, Matsumura H, Ishii T, Izuta T (2005). Establishing critical levels of air pollutants for protecting East Asian vegetation - A challenge. In: "Plant responses to air pollution and global change" (Omasa K, Nouchi I, De Kok LJ eds). Springer-Verlag, Tokyo, Japan, pp. 243-250. doi: 10.1007/4-431-31014-2_27

Lambers H, Chapin III FS, Pons TL (2008). Plant physiological ecology ( $2^{\text {nd }}$ edn). Springer, New York, USA, pp. 605.

Li P, Calatayud V, Gao F, Uddling J, Feng Z (2016). Differences in ozone sensitivity among woody species are related to leaf morphology and antioxidant levels. Tree Physiology 36: 11051116. - doi: 10.1093/treephys/tpwo42

Long SP, Bernacchi CJ (2003). Gas exchange measurements, what can they tell us about the underlying limitations to photosynthesis? Procedures and sources of error. Journal of Experimental Botany 54: 2393-2401. - doi: 10.1093/jxb/ erg262

Loreto F, Fares S (2013). Biogenic volatile organic compounds and their impacts on biosphere- atmosphere interactions. In: "Climate change, air pollution and global challenges: understanding and perspectives from forest research" (Matyssek R, Clarke N, Cudlin P, Mikkelsen TN, Tuovinen J-P, Wieser G, Paoletti E eds). Elsevier, Oxford, UK, pp. 57-75. - doi: 10.1016/B978-0-08098349-3.00004-9

McAinsh MR, Evans NH, Montgomery LT, North KA (2002). Calcium signalling in stomatal responses to pollutants. New Phytologist 153: 441-447. - doi: 10.1046/j.0028-646X.2001.0033 $6 . x$

Mills G, Harmens $H$, Hayes F, Pleijel H, Büker P, Gonzáles-Fernández I, Alonso R, Bender J, Bergmann E, Bermejo V, Braun S, Danielsson H, Gerosa G, Grünhage L, Karlsson PE, Marzuoli R, Schaub M, Simpson D (2017). III. Mapping critical levels for vegetation. In: "Manual on methodologies and criteria for modelling and mapping critical loads and levels and air pollution effects, risks and trends" (ICP Modelling and Mapping ed). UNECE Convention on Longrange Transboundary Air Pollution, Geneva, Switzerland, pp. 1-66. [online] URL: http:// www.icpmapping

Naja M, Akimoto H (2004). Contribution of regional pollution and long-range transport to the Asia-Pacific region: analysis of long-term ozonesonde data over Japan. Journal of Geophysical Research 109: D21306. - doi: 10.1029/ 2004JD004687

Nakanishi S, Ohba T, Takeda Y, Hattori T (1983). Illustration of vegetation in Japan. vol. I - Forest vegetation. Hoikusha Publishing Co. Ltd., Osaka, Japan, pp. 216.

Niinemets U, Tenhunen JD (1997). A model separating leaf structural and physiological effects on carbon gain along light gradients for the shade-tolerant species Acer saccharum. Plant, Cell and Environment 20: 845-866. - doi: 10.1046/j.1365-3040.1997.do1-133.x

Niinemets U, Tenhunen JD, Canta NR, Chavis MM, Faria T, Pereira JS, Reynolds JF (1999). Interactive effects of nitrogen and phosphorus on the acclimation potential of foliage photosynthetic properties of cork oak, Quercus suber, to elevated atmospheric $\mathrm{CO}_{2}$ concentrations. Global Change Biology 5: 455-470. - doi: 10.1046/j.1365-2486.1999.00241.x

Ohara T, Akimoto H, Kurokawa J, Horii N, Yamaji K, Yan X, Hatasaka T (2007). An Asian emission inventory of anthropogenic emission sources for the period 1980-2020. Atmospheric Chemistry and Physics 7: 4419-4444. - doi: 10.5194/ acp-7-4419-2007

Overmyer K, Kollist H, Tuominen H, Bets C, Langebartels C, Wingsle G, Kangasjärvi S, Brader G, Mullineauz P, Kangasjärvi J (2008). Complex phenotypic profiles leading to ozone sensitivity in Arabidopsis thaliana mutants. Plant, Cell and Environment 31: 1237-1249. - doi: 10.1111/j.13653040.2008.01837.x

R Development Core Team (2017). R: a language and environment for statistical computing. R Foundation for Statistical Computing, Vienna, Austria, pp. 3520. [online] URL: http://www.Rproject.org

Takashima T, Hikosaka K, Hirose T (2004). Photosynthesis or persistence: nitrogen allocation in leaves of evergreen and deciduous Quercus species. Plant, Cell and Environment 27: 1047-
1054. - doi: 10.1111/j.1365-3040.2004.01209.x Tani A, Kawawata Y (2008). Isoprene emission from the major native Quercus spp. in Japan. Atmospheric environment 42: 4540-4550. - doi: 10.1016/j.atmosenv.2008.01.059

Tissue DT, Lewis JD (2010). Photosynthetic responses of cottonwood seedlings grown in glacial through future atmospheric $\left[\mathrm{CO}_{2}\right]$ vary with phosphorus supply. Tree Physiology 30: 1361-1372. - doi: 10.1093/treephys/tpq077

Torsethaugen G, Pell EJ, Assmann SM (1999). Ozone inhibits guard cell $\mathrm{K}^{+}$channels implicated in stomatal opening. Proceedings of the National Academy of Sciences USA 96: 1257712582. - doi: 10.1073/pnas.96.23.13577

Vahisalu T, Puzõrjova I, Brosché M, Valk E, Lepiku M, Moldau H, Pechter P, Wang Y-S, Lindgren O, Salojärvi J, Loog $M$, Kangasjärvi J, Kollist $H$ (2010). Ozone-triggered rapid stomatal response involves the production of reactive oxygen species, and is controlled by SLAC1 and OST1. The Plant Journal 62: 442-453. - doi: 10.1111/j.1365-313X.2010.04159.x

Von Caemmerer S (2000). Biochemical models of leaf photosynthesis. CSIRO Publishing, Australia, pp. 152. [online] URL: http://books. google.com/books?id=Nxox4F3U7jgC

Warren CR, Adams MA (2004). Evergreen trees do not maximize instantaneous photosynthesis. Trends in Plant Science 9: 270-274. - doi: 10.1016/j.tplants.2004.04.004

Watanabe M, Yamaguchi M, Tabe C, Iwasaki M, Yamashita R, Funada R, Fukami M, Matsumura $\mathrm{H}$, Kohno Y, Izuta T (2007). Influences of nitrogen load on the growth and photosynthetic responses of Quercus serrata seedlings to $\mathrm{O}_{3}$. Trees 21: 421-432. - doi: 10.1007/s00468-0070134-2

Watanabe $M$, Yamaguchi $M$, Matsumura $H$, Kohno Y, Izuta T (2008). Effects of ozone on growth and photosynthesis of Castanopsis sieboldii seedlings grown under different nitrogen loads. Journal of Agricultural Meteorology 64: 143-155. - doi: 10.2480/agrmet.64.3.6

Watanabe M, Ryu K, Kita K, Takagi K, Koike T (2012). Effects of nitrogen load on the growth and photosynthesis of hybrid larch F1 (Larix gmelinii var. japonica $\times$ L. kaempferi) grown on serpentine soil. Environmental and Experimental Botany 83: 73-81. - doi: 10.1016/j.envexpbot. 2012.04.011

Watanabe M, Hoshika Y, Inada N, Wang X, Mao Q, Koike T (2013). Photosynthetic traits of Siebold's beech and oak saplings grown under free air ozone exposure. Environmental Pollution 174: 50-56. - doi: 10.1016/j.envpol.2012.11. 006

Watanabe M, Hoshika Y, Inada N, Koike T (2014). Canopy carbon budget of Siebold's beech (Fagus crenata) sapling under free air ozone exposure. Environmental Pollution 184: 682689. - doi: 10.1016/j.envpol.2013.04.018

Wittig VE, Ainsworth EA, Long SP (2007). To what extent do current and projected increases in surface ozone affect photosynthesis and stomatal conductance of trees? A metaanalytic review of the last 3 decades of experiments. Plant, Cell and Environment 30: 11501162. - doi: 10.1111/j.1365-3040.2007.01717.x

Wittig VE, Ainsworth EA, Naidu SL, Karnosky DF, Long SP (2009). Quantifying the impact of cur- 
rent and future tropospheric ozone on tree biomass, growth, physiology and biochemistry: a quantitative meta-analysis. Global Change Biology 15: 396-424. - doi: 10.1111/j.1365-2486. 2008.01774.x

Yamaguchi M, Watanabe M, Iwasaki M, Tabe C, Matsumura H, Kohno Y, Izuta T (2007). Growth and photosynthetic responses of Fagus crenata seedlings to $\mathrm{O}_{3}$ under different nitrogen loads. Trees 21: 707-718. - doi: 10.1007/s00468-007-016 3-x

Yamaguchi $M$, Watanabe $M$, Matsumura $H$, Kohno Y, Izuta T (2011). Experimental studies on the effects of ozone on growth and photosynthetic activity of Japanese forest tree species. Asian Journal of Atmospheric Environment 5: 65-87. - doi: 10.5572/ajae.2011.5.2.065

Yamaji K, Ohara T, Uno I, Kurokawa J, Pochanart $\mathrm{P}$, Akimoto $\mathrm{H}$ (2008). Future prediction of surface ozone over east Asia using models-3 com- munity multiscale air quality modeling system and regional emission inventory in Asia. Journal of Geophysical Research 113: Do8306.

Zhang W, Feng Z, Wang X, Niu J (2012). Responses of native broadleaved woody species to elevated ozone in subtropical China. Environmental Pollution 163: 149-157. - doi: 10.1016/ j.envpol.2011.12.035 